\title{
molecules
}

ISSN 1420-3049

www.mdpi.com/journal/molecules

Article

\section{Chemical Constituents from the Roots of Ranunculus ternatus and their Inhibitory Effects on Mycobacterium tuberculosis}

\author{
Ke-Zhong Deng ${ }^{1,2}$, Ying Xiong ${ }^{2, *}$, Bin Zhou ${ }^{3}$, Yong-Mei Guan ${ }^{2}$ and Yong-Ming Luo ${ }^{1,2, *}$ \\ 1 Beijing University of Chinese Medicine, Beijing 100029, China; E-Mail: dengkezhong@126.com \\ 2 Jiangxi University of Traditional Chinese Medicine, Nanchang 330004, China; \\ E-Mail: guanym2008@163.com \\ 3 Jiangxi Science and Technology Normal University, Nanchang 330038, China; \\ E-Mail: tju_zhoubin@163.com \\ * Authors to whom correspondence should be addressed; E-Mails: jzxiongying@126.com (Y.X.); \\ loym999@126.com (Y.-M.L.); Tel.: +86-791-8711-8993 (Y.-M.L.); \\ Fax: +86-791-8711-8834 (Y.-M.L.).
}

Received: 12 August 2013; in revised form: 14 September 2013 / Accepted: 17 September 2013 / Published: 25 September 2013

\begin{abstract}
Two new benzophenones, methyl (R)-3-[2-(3,4-dihydroxybenzoyl)-4,5dihydroxyphenyl]-2-hydroxypropanoate (1) and $n$-butyl $(R)$-3-[2-(3,4-dihydroxybenzoyl)4,5-dihydroxyphenyl]-2-hydroxypropanoate (2), were isolated from the roots of Ranunculus ternatus along with the two known compounds vanillic acid (3) and gallic acid (4). Their structures were elucidated by physical and spectroscopic analysis. In addition, compound $\mathbf{1}$ exhibited obvious activity against tuberculosis, while the activity of a 1:1 mixture of compound $\mathbf{1}$ plus $\mathbf{4}$ is better than that of $\mathbf{1}$ alone.
\end{abstract}

Keywords: Ranunculus ternatus; benzophenones; tuberculosis

\section{Introduction}

Ranunculus ternatus Thunb. (Ranunculaceae) is mainly distributed in the Henan and Anhui region of China and has been used in traditional Chinese medicine for the treatment of tuberculosis, faucitis and neck scrofula. Several lactones [1,2], flavonoids [3,4], triterpenoids [5], glycosides [6] and two alkaloids [7] have been isolated from the roots of this plant. Our previous phytochemical investigations on the crude drug revealed benzophenones [8]. It was reported that the extracts of Radix Ranuncoli 
Ternati such as the organic acid fraction had antimycobacterial activity in vitro [9]. However, very few reports have looked into the active ingredient(s) with antituberculosis effects, apart from ternatolide [10]. Here we describe the isolation of two novel benzophenones (compounds 1, 2) and two known substituted benzene compounds (compounds $\mathbf{3}, \mathbf{4}$ ) from $R$. ternatus, structure elucidation on the novel compounds and their inhibitory activity against $M$. tuberculosis.

\section{Results and Discussion}

The ethanol extract of the roots of $R$. ternatus was partitioned using various solvents (see Section 3 ) and the $\mathrm{H}_{2} \mathrm{O}$ soluble fraction was subsequently purified by repeated column chromatography (macroporous resin, ODS and Sephadex LH-20) to afford compounds 1-4 (Figure 1).

Figure 1. The structures of compounds $1-4$.<smiles>[R]COC(=O)[C@H](Cc1cc(O)c(O)cc1C(=O)c1ccc(O)c(O)c1)[Y7]([R])=O</smiles>

2: $\mathrm{R}=\mathrm{CH}_{2} \mathrm{CH}_{2} \mathrm{CH}_{3}$<smiles>[R]c1cc(C(=O)O)cc([R])c1O</smiles>

3: $\mathrm{R}_{1}=\mathrm{OCH}_{3} ; \mathrm{R}_{2}=\mathrm{H}$

4: $\mathrm{R}_{1}=\mathrm{OH} ; \mathrm{R}_{2}=\mathrm{OH}$

Compound 1 was obtained as a yellowish gum, $[\alpha]_{\mathrm{D}}^{18}+30.2$ (c $\left.0.1, \mathrm{MeOH}\right)$. Its molecular formula was established to be $\mathrm{C}_{17} \mathrm{H}_{16} \mathrm{O}_{8}$ by HRESI-MS ( $\mathrm{m} / \mathrm{z} 349.0919$, calcd. $349.0918[\mathrm{M}+\mathrm{H}]^{+}$). The IR bands at 3,264, 1,730, 1,590 and $1,519 \mathrm{~cm}^{-1}$ revealed the presence of hydroxyl, carbonyl and aromatic ring groups. The ${ }^{1} \mathrm{H}-\mathrm{NMR}$ spectrum (Table 1) of compound $\mathbf{1}$ show three aromatic protons signals at $\delta_{\mathrm{H}}$ $7.28(\mathrm{~d}, 1 \mathrm{H}, J=2.0 \mathrm{~Hz}), 7.17(\mathrm{dd}, 1 \mathrm{H}, J=8.0$ and $2.0 \mathrm{~Hz}), 6.82(\mathrm{~d}, 1 \mathrm{H}, J=8.0 \mathrm{~Hz})$ as an ABX-type system and two at $\delta_{\mathrm{H}} 6.79(\mathrm{~s}, 2 \mathrm{H})$. In addition, one methylene at $\delta_{\mathrm{H}} 3.04(\mathrm{dd}, 1 \mathrm{H}, J=13.6 \mathrm{and} 5.2 \mathrm{~Hz})$, $2.91\left(\mathrm{dd}, 1 \mathrm{H}, J=13.6\right.$ and $8.0 \mathrm{~Hz}$ ) and one oxygenated methine at $\delta_{\mathrm{H}} 4.30(\mathrm{dd}, 1 \mathrm{H}, J=8.0 \mathrm{and} 5.2 \mathrm{~Hz})$, as well as one methoxyl group at $\delta_{\mathrm{H}} 3.64(\mathrm{~s}, 3 \mathrm{H})$ were observed. The ${ }^{13} \mathrm{C}-\mathrm{NMR}$ spectrum (Table 1) combined with HSQC of compound 1 exhibited the signals for 17 carbons, including two phenyls, one carbonyl ketone and one carbonyl ester groups etc. In the HMBC spectrum (Figure 2), the correlation between H-3', H-2", H-6" and $\mathrm{C}=\mathrm{O}\left(\delta_{\mathrm{C}} 197.7\right)$ displayed that compound 1 possessed a diphenylketone skeleton. Moreover, H-3 correlated with C-1, C-2, C-2' and C-6'; H-2 correlated with C-1 and C-1'; $\mathrm{H}-4$ correlated with $\mathrm{C}-1$. The absolute configuration of $\mathrm{C}-2$ was determined as $\mathrm{R}$ by comparing its $\mathrm{CD}$ spectrum [219 $(\Delta \varepsilon-7.38), 289 \mathrm{~nm}(\Delta \varepsilon-0.618)]$ with that of ethyl $(S)$-3-[2-(3,4-dihydroxybenzoyl)4,5-dihydroxyphenyl]-2-hydroxypropanoate [219 $(\Delta \varepsilon+15.5), 273 \mathrm{~nm}(\Delta \varepsilon+1.99)]$ isolated from $R$. ternatus $[8,11,12]$. Based on the above evidence, the structure of compound 1 was elucidated to be methyl (R)-3-[2-(3,4-dihydroxybenzoyl)-4,5-dihydroxyphenyl]-2-hydroxypropanoate. 
Table 1. ${ }^{1} \mathrm{H}(400 \mathrm{MHz})$ and ${ }^{13} \mathrm{C}(100 \mathrm{MHz}) \mathrm{NMR}$ data of compounds 1 and 2 (in $\mathrm{CD}_{3} \mathrm{OD}, \delta \mathrm{ppm}, J \mathrm{~Hz}$ ).

\begin{tabular}{rcccc}
\hline \multirow{2}{*}{ No. } & \multicolumn{1}{c}{$\mathbf{1}$} & \multicolumn{2}{c}{$\mathbf{2}$} & \\
\cline { 2 - 5 } & $\boldsymbol{\delta}_{\mathbf{H}}$ & $\boldsymbol{\delta}_{\mathbf{C}}$ & $\boldsymbol{\delta}_{\mathbf{H}}$ & $\boldsymbol{\delta}_{\mathbf{C}}$ \\
\hline 1 & & 174.4 & & 174.2 \\
2 & $4.30(\mathrm{dd}, 1 \mathrm{H}, 8.0,5.2)$ & 71.9 & $4.25(\mathrm{dd}, 1 \mathrm{H}, 8.0,5.6)$ & 71.9 \\
3 & $3.04(\mathrm{dd}, 1 \mathrm{H}, 13.6,5.2)$ & 36.8 & $3.00(\mathrm{dd}, 1 \mathrm{H}, 13.6,5.6)$ & 37.0 \\
& $2.91(\mathrm{dd}, 1 \mathrm{H}, 13.6,8.0)$ & & $2.93(\mathrm{dd}, 1 \mathrm{H}, 13.6,8.0)$ & \\
4 & $3.64(\mathrm{~s}, 3 \mathrm{H})$ & 50.9 & $4.02(\mathrm{t}, 2 \mathrm{H}, 6.8)$ & 64.3 \\
5 & & & $1.52(\mathrm{~m}, 2 \mathrm{H})$ & 30.3 \\
6 & & & $1.29(\mathrm{~m}, 2 \mathrm{H})$ & 18.6 \\
7 & & 197.7 & $0.90(\mathrm{t}, 3 \mathrm{H}, 7.2)$ & 12.6 \\
CO & & 128.9 & & 197.7 \\
$1^{\prime}$ & & 130.3 & & 128.7 \\
$2^{\prime}$ & & 117.1 & $6.80(\mathrm{~s}, 1 \mathrm{H})$ & 130.4 \\
$3^{\prime}$ & $6.79(\mathrm{~s}, 1 \mathrm{H})$ & 142.6 & & 117.0 \\
$4^{\prime}$ & & 147.5 & & 142.7 \\
$5^{\prime}$ & & 117.9 & $6.80(\mathrm{~s}, 1 \mathrm{H})$ & 147.4 \\
$6^{\prime}$ & $6.79(\mathrm{~s}, 1 \mathrm{H})$ & 130.1 & & 118.0 \\
$1^{\prime}$ & & 116.8 & $7.29(\mathrm{~d}, 1 \mathrm{H}, 2.0)$ & 130.1 \\
$2^{\prime \prime}$ & $7.28(\mathrm{~d}, 1 \mathrm{H}, 2.0)$ & 144.8 & & 116.8 \\
$3^{\prime \prime}$ & & 150.9 & & 144.9 \\
$4^{\prime \prime}$ & & 114.2 & $6.81(\mathrm{~d}, 1 \mathrm{H}, 8.0)$ & 114.2 \\
$5^{\prime \prime}$ & $6.82(\mathrm{~d}, 1 \mathrm{H}, 8.0)$ & 124.4 & $7.17(\mathrm{dd}, 1 \mathrm{H}, 8.0,2.0)$ & 124.4 \\
$6^{\prime \prime}$ & $7.17(\mathrm{dd}, 1 \mathrm{H}, 8.0,2.0)$ & &
\end{tabular}

Figure 2. Structures and key HMBC $(\mathrm{H} \rightarrow \mathrm{C})$ correlations of compounds $\mathbf{1}$ and $\mathbf{2}$.

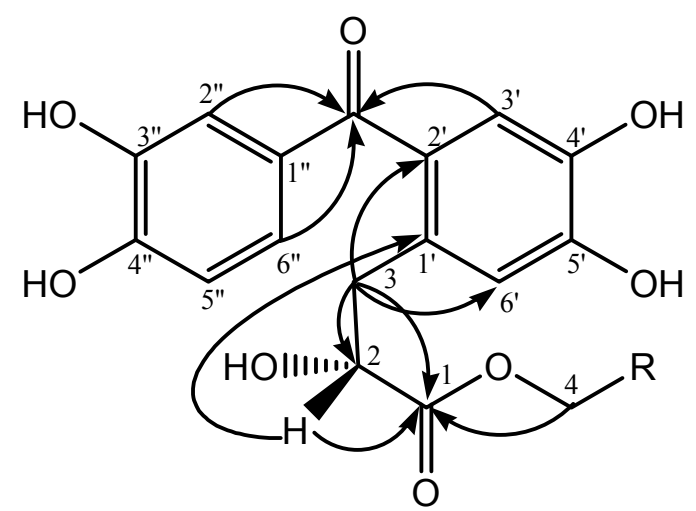

1: $\mathrm{R}=\mathrm{H} ; 2: \mathrm{R}=\mathrm{CH}_{2} \mathrm{CH}_{2} \mathrm{CH}_{3}$.

Compound 2 was obtained as a yellowish gum, $[\alpha]_{\mathrm{D}}^{18}+19.0$ (c $\left.0.06, \mathrm{MeOH}\right)$. Its HRESI-MS showed $[\mathrm{M}+\mathrm{H}]^{+}$at $\mathrm{m} / \mathrm{z} 391.1385$ (calcd. 391.1387), corresponding to the molecular formula $\mathrm{C}_{20} \mathrm{H}_{22} \mathrm{O}_{8}$. Its IR spectrum indicated the presence of hydroxyl $\left(3,291 \mathrm{~cm}^{-1}\right)$, carbonyl $\left(1,728 \mathrm{~cm}^{-1}\right)$ and aromatic rings $\left(1,592\right.$ and $\left.1,519 \mathrm{~cm}^{-1}\right)$. In comparison with compound $\mathbf{1}$, the spectra $\left({ }^{1} \mathrm{H}-,{ }^{13} \mathrm{C}-\mathrm{NMR},{ }^{1} \mathrm{H}-{ }^{1} \mathrm{H}\right.$ COSY, HSQC and HMBC) are quite similar, except for the methoxyl group of compound 1, which was replaced by an $n$-butoxy group $\left(\delta_{\mathrm{c}} 64.3,30.3,18.6,12.6\right)$ of compound 2 . By analysis of the HMBC spectrum, the correlation of $\mathrm{H}-4$ correlated with $\mathrm{C}-1$ indicated that the $n$-butoxy moiety was linked at 
the $\mathrm{C}-1$ position. Moreover, the $\mathrm{CD}$ spectrum showed a negative Cotton effect at $219(\Delta \varepsilon-7.09)$ and $276 \mathrm{~nm}(\Delta \varepsilon-0.502)$ [8,9], indicating the R-configuration of C-2. Thus, compound 2 was elucidated to be $n$-butyl ( $R$ )-3-[2-(3,4-dihydroxybenzoyl)-4,5-dihydroxyphenyl]-2-hydroxypropanoate.

The two known compounds, vanillic acid (3) and gallic acid (4), were identified by comparison of their physical and spectroscopic data with literature values [13]. All the compounds were evaluated for in vitro anti-tuberculosis activity against $M$. tuberculosis $\mathrm{H}_{37} \mathrm{Rv}$ (Table 2). Compounds 1, 2, vanillic acid (3) and gallic acid (4) are responsible for the antimycobacterial activity observed in $R$. ternatus. Compound $1(\mathrm{MIC}=41.67 \pm 14.43 \mu \mathrm{g} / \mathrm{mL})$ was the most active one. Furthermore, the activity of a 1:1 combination of compounds 1 and $4(\mathrm{MIC}=20.83 \pm 7.22 \mu \mathrm{g} / \mathrm{mL})$ was better than that of 1 alone.

Table 2. MIC values $(\mu \mathrm{g} / \mathrm{mL})$ of constituents from $R$. ternatus against M. tuberculosis.

\begin{tabular}{ccccccc}
\hline \multicolumn{7}{c}{ Sample } \\
\hline $\mathbf{1}$ & $\mathbf{2}$ & $\mathbf{3}$ & $\mathbf{4}$ & Mixture of 1 + 3 (1:1) & Mixture of 1 + 4 (1:1) & Control \\
\hline $41.67 \pm 14.43 *$ & $266.67 \pm 115.47$ & $83.33 \pm 28.87 *$ & $66.67 \pm 28.87$ & $83.33 \pm 28.87 *$ & $20.83 \pm 7.22 *$ & $2.08 \pm 0.90$ \\
\hline \multicolumn{7}{c}{ Each value represents the mean \pm S.D. $(n=3)$. Compared with sample of control group. * $p<0.05}$.
\end{tabular}

\section{Experimental}

\subsection{General Procedures}

Optical rotations were measured on a WZZ-1 automatic polarimeter. IR spectra were obtained on a Bio-Rad FTS 6000 infrared spectrometer. HRESIMS spectra were performed on an Ionspec 7.0 T FTICR MS. 1D- and 2D-NMR spectra were recorded on a Bruker AVANCE-400 $\left(400 \mathrm{MHz}\right.$ for ${ }^{1} \mathrm{H}-$ and $100 \mathrm{MHz}$ for ${ }^{13} \mathrm{C}-$ ) NMR spectrometer using TMS as an internal standard. Preparative HPLC was carried out on an ODS column $(250 \times 20 \mathrm{~mm}$, YMC) with a CXTH LC-3000 UV-detector. Silica gel (200-300 mesh, Qingdao Ocean Chemical Group Co., Qingdao, China) and Sephadex LH-20 (Merck Co., Darmstadt, Germany) for column chromatography as well as silica gel GF254 (Qingdao Ocean Chemical Group Co. of China) for TLC were used.

\subsection{Plant Material}

The roots of Ranunculus ternatus were purchased from Zhangshu, Jiangxi Province, China and was identified by Associate Prof. Ke-Zhong Deng. A voucher specimen (voucher specimen No. RT1101) is deposited in the School of Pharmacy, Jiangxi University of Traditional Chinese Medicine, China.

\subsection{Extraction and Isolation}

The roots of Ranunculus ternatus ( $25 \mathrm{~kg}$ ) were powdered and successively extracted with $95 \%$ and $65 \% \mathrm{EtOH}(100 \mathrm{~L}, 2 \mathrm{~h} \times 3$, respectively) under reflux for two hours and then filtered. After removal of the solvent under reduced pressure, the residue $(4 \mathrm{~kg})$ was suspended in water and partitioned with light petroleum ether and EtOAc successively. The remaining water soluble fraction $(2,580 \mathrm{~g})$ was passed through a macroporous resin column (Amberlite XAD 16) and eluted with $\mathrm{H}_{2} \mathrm{O}-\mathrm{EtOH}$ $(1: 0 \rightarrow 0: 95, v / v)$ to give 12 fractions. Fraction $5(12 \mathrm{~g})$ was loaded on an open ODS column and eluted with $\mathrm{H}_{2} \mathrm{O}-\mathrm{MeOH}(9: 1 \rightarrow 0: 1, v / v)$ to give nine subfractions. Sub-fraction 4 was subjected to preparative 
HPLC (YMC-pack ODS-A, $250 \mathrm{~mm} \times 20 \mathrm{~mm}, \mathrm{MeOH} / \mathrm{H}_{2} \mathrm{O} 3: 7,5 \mathrm{~mL} / \mathrm{min}$ ) to afford compound 1 (24 mg) and 4 (18 mg), Sub-fraction 6 was separated by preparative HPLC (YMC-pack ODS-A, $250 \mathrm{~mm} \times 20 \mathrm{~mm}, \mathrm{MeOH} / \mathrm{H}_{2} \mathrm{O} 5: 5,5 \mathrm{~mL} / \mathrm{min}$ ) and purified on a Sephadex LH-20 column eluted with $\mathrm{MeOH}$ to yield compounds 2 (38 $\mathrm{mg})$ and $\mathbf{3}(8 \mathrm{mg})$.

3.3.1. Methyl (R)-3-[2-(3,4-dihydroxybenzoyl)-4,5-dihydroxyphenyl]-2-hydroxypropanoate (1)

Yellowish gum; $[\alpha]_{\mathrm{D}}^{18}+30.2$ (c 0.10, MeOH); IR bands (KBr): 3,264, 2,957, 1,731, 1,591, 1,519, 1,441, 1,366, 1,296, 1,222, 1,160, 1,115, 1,024, 889, 833, 783, 771, $631 \mathrm{~cm}^{-1}$; positive ion HRESIMS $\mathrm{m} / z$ : $[\mathrm{M}+\mathrm{H}]^{+} 349.0919$ for $\mathrm{C}_{17} \mathrm{H}_{16} \mathrm{O}_{8}+\mathrm{H}$ (calcd. 349.0918); ${ }^{1} \mathrm{H}-\mathrm{NMR}\left(\mathrm{CD}_{3} \mathrm{OD}, 400 \mathrm{MHz}\right)$ and ${ }^{13} \mathrm{C}-\mathrm{NMR}$ $\left(\mathrm{CD}_{3} \mathrm{OD}, 100 \mathrm{MHz}\right)$ are shown in Table 1.

3.3.2. n-Butyl (R)-3-[2-(3,4-dihydroxybenzoyl)-4,5-dihydroxyphenyl]-2-hydroxypropanoate (2)

Yellowish gum; $[\alpha]_{\mathrm{D}}^{18}+19.0$ (c 0.06, MeOH); IR bands (KBr): 3,291, 2,961, 1,728, 1,592, 1,518, 1,441, 1,372, 1,295, 1,216, 1,160, 1,113, 1,083, 892, 834, 783, $630 \mathrm{~cm}^{-1}$; positive ion HRESIMS $\mathrm{m} / z$ : $[\mathrm{M}+\mathrm{H}]^{+} 391.1385$ for $\mathrm{C}_{17} \mathrm{H}_{16} \mathrm{O}_{8}+\mathrm{H}$ (calcd. 391.1387); ${ }^{1} \mathrm{H}-\mathrm{NMR}\left(\mathrm{CD}_{3} \mathrm{OD}, 400 \mathrm{MHz}\right)$ and ${ }^{13} \mathrm{C}-\mathrm{NMR}$ $\left(\mathrm{CD}_{3} \mathrm{OD}, 100 \mathrm{MHz}\right)$ are shown in Table 1.

\subsection{Anti-Tuberculosis Activity}

Anti-mycobacterial activities of compounds 1-4 against $M$. tuberculosis strains $\mathrm{H}_{37} \mathrm{Rv}$ (strains were obtained from the Jiangxi Province Centers for Disease Prevention and Control, Nanchang, China) were evaluated by the Microplate Alamar Blue Assay [14]. The MIC (minimum inhibitory concentration) values were determined and compared with rifampicin as a reference drug.

\section{Conclusions}

Two new benzophenones (compounds 1, 2) together with two known organic acids (compounds 3, 4) were isolated from $R$. ternatus Thunb. Compounds 1-4 were assayed for their anti-tuberculosis activity and the data proved that comound $\mathbf{1}$ had significant inhibitory activity, furthermore, the activity of a mixture of compounds $\mathbf{1}$ and $\mathbf{4}$ is better than that of $\mathbf{1}$ alone. Up to now, natural benzophenones that exhibited anaphylaxis, inflammatory, alpha-glucosidase and HIV inhibition activity have been reported from species of the Clusiaceae, Thymelaeaceae, Myrtaceae and Iridaceae, etc. [15-19]. The substituents on the phenyl ring usually are hydroxyl, methoxy and isopentene groups. Benzophenones which possess propionate ester groups with a chiral carbon were only found in $R$. ternatus of the Ranunculaceae. This is the first report about benzophenones as potential anti-tuberculosis inhibitors.

\section{Supplementary Materials}

Supplementary materials can be accessed at: http://www.mdpi.com/1420-3049/18/10/11859.

\section{Acknowledgments}

This research work was supported by National Natural Science Foundation of China (No. 81060334). 


\section{Conflicts of Interest}

The authors declare no conflict of interest.

\section{References}

1. Guo, X.M.; Zhou, Z.L.; Hong, Y.F. Studies on the chemical constituents of Ranunculus ternatus Thunb. Acta Pharm. Sin. 1995, 30, 931-934.

2. Xiong, Y.; Deng, K.Z.; Gao, W.Y.; Guo, Y.Q. Studies on the chemical constituents of Ranunculus ternatus. Chin. J. Chin. Mater. Med. 2008, 33, 909-911.

3. Zhang, X.G.; Tian, J.K. Studies on chemical constituents of Ranunculus ternatus (III). Chin. Pharm. J. 2006, 41, 1460-1461.

4. Xiong, Y.; Deng, K.Z.; Guo, Y.Q.; Gao, W.Y. Studies on the chemical constituents of flavonoids and glycosides in Ranunculus ternatus. Chin. Tradit. Herb. Drugs 2008, 39, 1449-1452.

5. Zhao, Y.; Ruan, J.L.; Wang, J.H.; Kong, Y.; Song, S.; Cai, Y.L.; Fang, W.; Zhou, D.L. Chemical constituents of radix Ranunculus ternati. Nat. Prod. Res. 2008, 22, 233-240.

6. Tian, J.K.; Sun, F.; Cheng, Y.Y. Two new glycosides from the roots of Ranunculus ternatus. Chin. Chem. Lett. 2005, 16, 928-930.

7. Zhang, L.; Yang, Z.; Tian, J.K. Two new indolopyridoquinazoline alkaloidal glycosides from Ranunculus ternatus. Chem. Pharm. Bull. 2007, 55, 1267-1269.

8. Xiong, Y.; Deng, K.Z.; Gao, W.Y.; Guo, Y.Q. A novel alkenoic acid ester and a new benzophenone from Ranunculus ternatus. Chin. Chem. Lett. 2007, 18, 1364-1366.

9. Chi, Y.M.; Yang, Y.Q.; Yu, S. Effect and composition of organic acid of radix Ranunculus ternati. J. Nanjing TCM Univ. 2007, 23, 365-367.

10. Ji, X.Y.; Li, S.Y.; Meng, S.; Xiao, C.L.; You, X.F.; Li, Z.R. Synthesis and antimycobacterial activity of ternatolide. J. Chin. Pharm. Sci. 2012, 21, 265-268.

11. Verbit, L.; Heffron, P.J. Optically active aromatic chromophores-IV circular dichroism studies of some open-chain system. Tetrahedron 1968, 24, 1231-1236.

12. Yahara, S.; Satoshiro, M.; Nishioka, I.; Nagasawa, T.; Oura, H. Isolation and characterization of phenolic compounds from Coptidis Rhizoma. Chem. Pharm. Bull. 1985, 33, 527-531.

13. Wang, X.M.; Zhang, Q.; Rena, K.; Wang, X.L.; Wang, X.Q. Chemical constituents in whole plant of Cynomorium songaricum. Chin. Tradit. Herb. Drugs 2011, 42, 458-460.

14. Camacho, C.M.R.; Ramírez, C.M.A.; González, S.O.; Garza, G.E.; Palacios, I.P.; Luna, H.J. Activity against drug resistant-tuberculosis strains of plants used in Mexican traditional medicine to treat tuberculosis and other respiratory diseases. Phytother. Res. 2008, 22, 82-85.

15. Fu, H.Z.; Yang, J.Z.; Li, C.J.; Zhang, M.D. A new benzophenone glycoside from the leaves of Psidium guajava L. Chin. Chem. Lett. 2011, 22, 178-180.

16. Feng, J.; Yang, X.W.; Wang, R.F. Bio-assay guided isolation and identification of $\alpha$-glucosidase inhibitors from the leaves of Aquilaria sinensis. Phytochemistry 2011, 72, 242-247.

17. Orawan, M.; Wanchai, D.E.; Kaoru, U.; Yohko, Y.; Toshio, M.; Tsutomu, W.; Hiroshi, N. Phenolic constituents of the rhizomes of the thai medicinal plant Belamcanda chinensis with proliferative activity for two breast cancer cell lines. J. Nat. Prod. 2005, 68, 361-364. 
18. Lee, S.S.; Tseng, C.C.; Chen, C.K. Three new benzophenone glucosides from the leaves of Planchonella obovata. Helv. Chim. Acta 2010, 93, 522-529.

19. Nguyen, H.D.; Trinh, B.T.D.; Tran, Q.N.; Nguyen, H.D.; Pham, H.D.; Hansen, P.E.; Duus, F.; Connolly, J.D.; Nguyen, L.H.D. Friedolanostane, friedocycloartane and benzophenone constituents of the bark and leaves of Garcinia benthami. Phytochemistry 2011, 72, 290-295.

Sample Availability: Not available.

(C) 2013 by the authors; licensee MDPI, Basel, Switzerland. This article is an open access article distributed under the terms and conditions of the Creative Commons Attribution license (http://creativecommons.org/licenses/by/3.0/). 